\title{
Marketing, Tourism, and International Business Journal Rankings 2014: The Vox Populi Approach
}

\author{
James E. Richard \\ The School of Marketing and International Business, Victoria University of Wellington \\ Kelburn, Wellington, New Zealand.

\section{Kim-Shyan Fam} \\ The School of Marketing and International Business, Victoria University of Wellington \\ Kelburn, Wellington, New Zealand.
}

\section{Hiram Ting}

Sarawak Research Society, Kuching, Malaysia

\begin{abstract}
The ranking of academic journals continues to be a contentious issue in the tertiary education environment. Academics dependency on journal ranking for tenure and promotion, based on perceived quality and prestige of journals, ensures debate over what constitutes a "good" journal publication. This study utilises the vox populi MAG score established in previous research in order to continue the assessment of journal ranking and impact in the field of marketing. The current findings are consistent with the previous 2009 and 2011 study; the top six journals remain the same, there is little variation within the top 30 journal rankings, although regional differences are apparent. The ranking results from a broad range of academics continue to provide a comprehensive measure of journal impact from the perspective of academics.
\end{abstract}

Keywords: Journal Ranking, Impact Factor, Vox Populi, Marketing, Ranking Criteria 


\section{Introduction}

Journal rankings and academic quality continues to attract attention from social science academics, education management and policy makers (Herndon 2016). Publishing in top journals have become synonymous for academic quality, reflecting the research value of academics, and representing institutional excellence. Fortunately, (or unfortunately), a number of "quality" journal lists exist (e.g., Scopus, SSCI, UTD, RAE/REF, ABDC) and continue to be used to influence academic hiring, tenure, promotion decisions, and individual evaluation (Saunders and Wong 2011).

This study is the third in a planned series of triennial longitudinal studies examining the ranking of journals by academics around the world, including the personal and career impact on academics of publishing in ranked journals. The current paper only presents the journal ranking data for discussion. As in the previous two studies (Fam, Shukla, Sinha, Parackel and Chai 2011; Richard, Fam, Plimmer and Gerschewski 2012), the research endeavours to understand the effect of journal ranking from the "contributor" perspective, using the vox populi approach. This approach attempts to address the direction suggested by Steward and Lewis (2010) that "...efforts aimed at creating new perspectives on appraising the quality of journals in Marketing should be encouraged".

The study contributes to the ongoing discourse on business research quality assessment and journal ranking by examining marketing academic publication ranking across a representative academic spectrum (e.g., from lecturers to professors), not solely based on leading business schools or the academic elite (Theoharakis and Hirst 2002). In addition the study considers the relative impact of a number of journal ranking criteria, the journals in which academics actually publish, and identifies differences between regions. The vox populi approach, considering views from a wide range of academics from around the world provides a more balanced view of journal quality. The study compares the results against two other generally accepted impact factor based journal ranking lists, and suggest additional research.

\section{Methodology}

Academics were asked to freely recall and nominate up to ten journals considered to be "A" grade (or higher). In the current case, this method was used to assess academics awareness (unaided recall) of top rated journals (Till and Baac 2005).

\section{Sampling}

This study developed a sampling frame of academics by scanning marketing, tourism, and international business departmental web sites of universities across the five continents. In total, 11,117 potential respondents were identified from Shanghai Jiao Tong University Ranking 2010 List, Times Supplement University Ranking 2010 List (excluding academics not listed on the Shanghai Jiao Tong List), ANZMAC Conference Directory of Academics, and a further 300 universities located in South Africa, Asia/South Pacific, Australia, New Zealand, USA, Middle East, South America and Europe that were not present on any of the above lists. Respondents included academics from all levels (lecturers, senior lecturers, assistant 
professors, associate professors, professors, and chair professors). Two weeks following the initial email invitation, a follow-up email was sent.

\section{Survey Instrument}

The survey instrument asked respondents to recall and rank up to ten A-grade journals.

"List the journals you consider to be an "A" grade (including $\mathrm{A}+$ ) in your research area"

In addition, the respondents were asked to list the journals they had published in since 2011 .

"Please list the journals you have published in since 2011"

Respondents were also asked to indicate the importance of specific journal ranking criteria; perceptive studies, Citation, Impact Factor, Rejection rate, Contribution to knowledge, Contribution to career promotion/progression, Esteem, and Usefulness for research students.

Country, age and years as an academic information was also collected.

\section{Result}

Of the 11,117 potential respondents contacted by email, 317 returned out of office auto-generated messages, 2,729 had "undeliverable" e-mails (e.g., invalid e-mail addresses), 30 others declined to participate and 6,857 provided no response to either email. In total there were 1,184 respondents giving an overall response rate of $10.7 \%$. Following data cleaning and verification, 503 respondents did not provide journal rankings, the final sample size was 681 cases $(6.1 \%)$. This number of respondents was a decrease from the previous study (Richard et al. 2012). The respondents were full-time academics from marketing, marketing tourism or international business.

The file was examined visually for appropriate journal names, standard journal names (from the journal site) were adopted, the data reviewed, and journal names revised to reflect the standard journal names. Formulas were created to sort the journals and the different ranking were calculated. The cleaned and verified data was then input into SPSS for analysis.

\section{Survey Data Analysis}

Table 1 indicates that the single highest numbers of, 169 (36.3\%), were late-career academics, with more than 20 years' service, while $50.0 \%$ (233) were mid-career with 6 to 20 years' service. The majority of the respondents $39.4 \%$ ( 267 aged 45 to 64) were well established in their academic career. There were 337 males $(49.5 \%)$ and 127 females (18.6\%), 217 respondents did not report their gender. 
Table 1: Age and Years as an Academic

\begin{tabular}{lcc|ccccc}
\hline \multirow{2}{*}{ Age } & \multirow{2}{*}{ Frequency } & \multirow{2}{*}{ Percent } & \multicolumn{5}{c}{ Years as an academic } \\
\cline { 4 - 8 } & & & \multicolumn{1}{c|}{} & $\mathbf{2}$ to 5 & $\mathbf{6}$ to 10 & $\mathbf{1 1}$ to 20 & $>\mathbf{2 1}$ \\
\hline 25 to 34 & 33 & 4.8 & 3 & 20 & 10 & 0 & 0 \\
\hline 35 to 44 & 117 & 17.2 & 2 & 29 & 56 & 29 & 0 \\
\hline 45 to 54 & 137 & 20.0 & 0 & 8 & 19 & 74 & 36 \\
\hline 55 to 64 & 132 & 19.4 & 0 & 2 & 9 & 31 & 88 \\
\hline 65 to 70 & 39 & 6.0 & 0 & 0 & 3 & 2 & 34 \\
\hline 71 or over & 11 & 1.6 & 0 & 0 & 0 & 0 & 11 \\
\hline Missing & 212 & 31.0 & - & - & - & - & - \\
\hline & 681 & 100 & 5 & 59 & 97 & 136 & 169 \\
\hline
\end{tabular}

The majority of respondents are from the United States of America (34.0\%), followed by Australia (9.0\%), the United Kingdom (7.3\%), New Zealand (4.0\%) and Canada (2.2\%), see Table 2 . This compares favourably with the previous survey, although 219 (32.1\%) respondents did not provide their country of residence.

Table 2: Respondents by Country

\begin{tabular}{lcc|lcc}
\hline Country & Frequency & Percent & Country & Frequency & Percent \\
\hline United States of America & 230 & 34.0 & Netherlands & 2 & 0.3 \\
\hline Australia & 58 & 9.0 & Republic of Korea & 2 & 0.3 \\
\hline United Kingdom & 50 & 7.3 & Singapore & 2 & 0.3 \\
\hline New Zealand & 27 & 4.0 & Sweden & 2 & 0.3 \\
\hline Canada & 15 & 2.2 & Albania & 1 & 0.1 \\
\hline France & 7 & 1.0 & Brazil & 1 & 0.1 \\
\hline Hong Kong & 7 & 1.0 & Egypt & 1 & 0.1 \\
\hline China & 6 & 0.9 & Estonia & 1 & 0.1 \\
\hline Denmark & 6 & 0.9 & Germany & 1 & 0.1 \\
\hline Ireland & 6 & 0.9 & Hungary & 1 & 0.1 \\
\hline United Arab Emirates & 5 & 0.7 & India & 1 & 0.1 \\
\hline Finland & 4 & 0.6 & Lebanon & 1 & 0.1 \\
\hline Malaysia & 4 & 0.6 & Qatar & 1 & 0.1 \\
\hline South Africa & 4 & 0.6 & Thailand & 1 & 0.1 \\
\hline Norway & 3 & 0.4 & Turkey & 1 & 0.1 \\
Indonesia & 2 & 0.3 & Uganda & 0.1 \\
\hline Israel & 2 & 0.3 & United Republic of Tanzania & 1 & 0.1 \\
\hline Jordan & 2 & 0.3 & Uruguay & 1 & 0.1 \\
\hline Kuwait & 2 & 0.3 & Missing & 219 & 32.1 \\
\hline & & & Total & $\mathbf{6 8 1}$ & $\mathbf{1 0 0 . 0}$ \\
\hline
\end{tabular}

\section{Journal Ranking}

The six top rated journals included Journal of Marketing with the highest number of unaided recalls, 441 (64.8\%), followed by Journal of Marketing Research with 388 (57.0\%) unaided recalls, Journal of Consumer Research with 362 (53.2\%), Marketing Science with 279 (41.0\%), Journal of Retailing with 156 (22.9\%), and the Journal of Consumer Psychology with 116 (17.0\%). 
Overall, the academics who responded indicated that they had published 2,166 articles in 823 journals over the last four years, from 2011 until 2014; an average of 3.18 publications per academic. Of these articles, 266 (12.3\%) were published in the top ten ranked journals with 31 (1.4\%) papers published in the Journal of Marketing, 26 (1.2\%) papers in the Journal of Marketing Research, 24 (1.1\%) papers in the Journal of Consumer Research, 19 (0.9\%) papers in Marketing Science, 31 (1.4\%) papers in the Journal of Academy of Marketing Science and 24 (1.1\%) papers in the Journal of Retailing. A total of 155 papers were published in the six top-ranked journals, see Table 3.

Table 3: Top 6 Journal Publications by Region

\begin{tabular}{lccccccccc}
\hline Top Ranked Journals & Overall & NA & UK & ANZ & Asia & Europe & ROW & NK \\
\hline Journal of Marketing & 31 & 21 & 0 & 3 & 0 & 1 & 0 & 6 \\
\hline Journal of Marketing Research & 26 & 16 & 0 & 1 & 2 & 0 & 0 & 7 \\
\hline Journal of Consumer Research & 24 & 15 & 0 & 2 & 0 & 2 & 0 & 5 \\
\hline Marketing Science & 19 & 12 & 0 & 2 & 0 & 0 & 0 & 5 \\
\hline Journal of Academy of Marketing Science & 31 & 21 & 1 & 1 & 1 & 3 & 0 & 4 \\
\hline Journal of Retailing & 24 & 14 & 2 & 0 & 0 & 1 & 0 & 7 \\
\hline Total Top Ranked journal publications & 155 & 99 & 3 & 9 & 3 & 7 & 0 & 34 \\
\hline Total Publications & 2,166 & 837 & 212 & 364 & 87 & 133 & 74 & 459 \\
\hline
\end{tabular}

Note: See Appendix A for the list of countries included in each region. ROW $=$ Rest of the World. NK = Not Known, region missing.

Regionally, US academics reported the highest number of publications in the Journal of Marketing (19, Canada with 2), and the highest number of top rated publications overall with 92, (Canada had 7 top rated publications).

Table 4 shows that although the top ten rankings are similar, there are some significant regional differences. Outside North America international and European related journals are ranked higher, especially by the UK respondents. The European Journal of Marketing is ranked highest by the UK, Australia and New Zealand, which may represent a shift in research toward a more European focus.

Table 4: Top Ten Marketing Journals Ranked by Region

\begin{tabular}{lcccccc}
\hline & \multicolumn{5}{c}{ Journal Rank by Region } \\
Journal & NA & ANZ & UK & Eur & Asia & ROW \\
\hline Journal of Marketing & $\mathbf{1}$ & $\mathbf{1}$ & $\mathbf{1}$ & $\mathbf{1}$ & $\mathbf{1}$ & $\mathbf{3}$ \\
\hline Journal of Marketing Research & $\mathbf{2}$ & $\mathbf{3}$ & $\mathbf{5}$ & $\mathbf{3}$ & $\mathbf{2}$ & $\mathbf{1}$ \\
\hline Journal of Consumer Research & $\mathbf{3}$ & $\mathbf{2}$ & $\mathbf{2}$ & $\mathbf{2}$ & $\mathbf{5}$ & $\mathbf{1}$ \\
Marketing Science & $\mathbf{4}$ & $\mathbf{4}$ & $\mathbf{7}$ & $\mathbf{4}$ & $\mathbf{5}$ & $\mathbf{4}$ \\
\hline Journal of Retailing & $\mathbf{5}$ & $\mathbf{6}$ & $\mathbf{5}$ & $\mathbf{7}$ & $\mathbf{5}$ & $\mathbf{7}$ \\
\hline Journal of Consumer Psychology & $\mathbf{6}$ & $\mathbf{1 0}$ & 25 & 11 & 18 & $\mathbf{1 0}$ \\
Management Science & $\mathbf{7}$ & 23 & 34 & 40 & 19 & 14 \\
Journal of Business Research & $\mathbf{8}$ & $\mathbf{6}$ & $\mathbf{9}$ & 40 & $\mathbf{8}$ & $\mathbf{6}$ \\
\hline Journal of Advertising & $\mathbf{9}$ & $\mathbf{1 0}$ & 34 & - & 17 & $\mathbf{9}$ \\
\hline Academy of Management Journal & $\mathbf{1 0}$ & 15 & 54 & $\mathbf{9}$ & 15 & 14 \\
European Journal of Marketing & 39 & $\mathbf{4}$ & $\mathbf{3}$ & 12 & 19 & 14 \\
\hline
\end{tabular}




\begin{tabular}{lcccccc}
\hline International Journal of Research in Marketing & 14 & $\mathbf{8}$ & $\mathbf{1 0}$ & $\mathbf{5}$ & 29 & - \\
\hline Journal of Marketing Management & 55 & $\mathbf{9}$ & $\mathbf{4}$ & 21 & 29 & 14 \\
\hline Journal of Academy of Marketing Science & 121 & 12 & $\mathbf{8}$ & $\mathbf{6}$ & $\mathbf{3}$ & $\mathbf{4}$ \\
\hline Journal of International Business Studies & 13 & 15 & 25 & $\mathbf{8}$ & $\mathbf{8}$ & 14 \\
\hline Strategic Management Journal & 11 & - & 34 & $\mathbf{9}$ & $\mathbf{8}$ & - \\
\hline Annals of Tourism Research & 25 & 15 & 13 & 14 & $\mathbf{4}$ & - \\
\hline Marketing Letters & 20 & 12 & 54 & 40 & - & $\mathbf{8}$ \\
\hline Journal of Service Research & 18 & 23 & 11 & 21 & 19 & $\mathbf{1 0}$ \\
\hline
\end{tabular}

Note: the relative position of journals outside of other region's top ten are shown in small italicised font. NA = North America, ANZ = Australia \& New Zealand, UK $=$ United Kingdom, Eur $=$ Europe, ROW $=$ Rest of the World.

To explore whether the large number of US respondents biased the journal rankings, the data was analysed without the US data $(n=230)$, see Appendix D for details of the top 100 journals. Five of the six top ranked journals are the same with and without the US data. The Journal of the Academy of Marketing Science is ranked above the Journal of Consumer Psychology when US data is not included. The US and non-US data is similar through the top 17 rankings; however, the journal ranking with US data includes the Journal of Marketing Management, and the Annals of Tourism Research in the top 20, which was not the case in the 2011 ranking data.

\section{Ranking Criteria}

In addition to the journal ranking exercise, each respondent was also asked to indicate the relative importance (weighting) of eight factors in ranking journals, see Table 5. In order to ensure relative weighting was considered, each respondent provided a weighting for each of the eight factors which had to total to $100 \%$.

Table 5: Journal Ranking Criteria as Perceived by Respondents: Comparing 2011 and 2014 Results, and by Region

\begin{tabular}{lcc|cc|c|c|c|c|c|c} 
& \multicolumn{2}{c}{$\mathbf{2 0 1 1}$} & \multicolumn{2}{c|}{$\mathbf{2 0 1 4}$} & \multicolumn{4}{c}{ Criteria Rank by Region } \\
\cline { 2 - 10 } Criteria & Weight & Rank & Weight & Rank & NA & ANZ & UK & EUR & Asia & ROW \\
\hline Citations & - & - & 25.2 & 1 & 1 & 1 & 1 & 1 & 1 & 1 \\
Impact factor & 24.64 & 1 & 20.2 & 2 & 2 & 2 & 2 & 2 & 2 & 2 \\
Perceptive studies & 18.84 & 2 & 17.0 & 3 & 3 & 4 & 3 & 3 & 3 & 3 \\
Contribution to knowledge & 18.48 & 3 & 13.8 & 4 & 4 & 3 & 4 & 4 & 5 & 4 \\
Contribution to career & 10.87 & 4 & 7.2 & 5 & 6 & 8 & 5 & 6 & 4 & 5 \\
Rejection rate & 9.59 & 5 & 6.6 & 6 & 5 & 6 & 8 & 5 & 8 & 8 \\
Esteem factors & 8.68 & 7 & 5.6 & 7 & 7 & 5 & 6 & 7 & 7 & 7 \\
Useful for research students & 8.9 & 6 & 4.6 & 8 & 8 & 7 & 7 & 8 & 6 & 6 \\
\hline
\end{tabular}

The results showed that across all regions, citations provide the greatest impact on perceived ranking, with a weighting of 25.2, followed by impact factor with a weighting of 20.2. Perceptive studies and contribution to knowledge were also major contributors to journal ranking. Regional differences are apparent from the third criteria onwards; Australia and New Zealand consider contribution to knowledge the third most important criteria, and contribution to career least important, while Asia 
considered contribution to career the fourth most important criteria, rather than contribution to knowledge.

\section{MAG Score}

MAG Scholar is the abbreviation for the Marketing in Asia Group (www.magscholar.com) which initiated and supports the ongoing study. The study designed a formula to capture the relative standing of these journals. Since each journal has its own merits, the first unaided recalled journal is allocated more weight than the second, third, fourth, and so on, recalled journal, until the tenth position. The sum of each journal's value is labelled the MAG score, and this score is used to rank the journal relative to the others, see Appendix B for example.

\section{MAG score $\left.=\sum_{j}\left(\left(\mathbf{R}_{i j} / \sum \mathbf{T}_{j}\right)\right) / \operatorname{Rank}_{j}\right)$}

Note: $\mathrm{R}_{i j}$ is the number of unaided recalls for the $i^{\text {th }}$ journal $(i=1-632)$ with $j^{\text {th }}$ rank $(j=1,2,3, \ldots, 10)$, and $\mathrm{T}$ is the total number of unaided

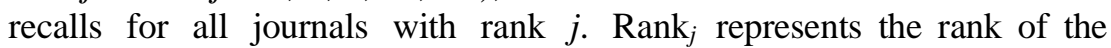
journal.

In addition, a MAG index was computed where a value of " 100 " was attributed to the number 1 journal. The indices for the remaining journals were calculated based on their respective MAG scores relative to the number 1 journal. Table 6 contains the top 50 MAG journals based on the number of journal recalls; the MAG scores combined with the MAG index was used to guide the rank separations. For comparative purposes, Table 6 also shows the 2009 and 2011 MAG journal ranking. The complete list of journal rankings can be found at www.magscholar.com. 
Table 6: Top 50 Ranked Marketing Journals, Based on Recall, and Calculated MAG Scores

\begin{tabular}{|c|c|c|c|c|c|c|c|}
\hline \multicolumn{4}{|c|}{ Ranking } & \multicolumn{4}{|c|}{2014} \\
\hline 2009 & 2011 & 2014 & Journal & $\begin{array}{c}\text { Total } \\
\text { Recalls }\end{array}$ & $\begin{array}{l}\text { MAG } \\
\text { Score }\end{array}$ & $\begin{array}{l}\text { MAG } \\
\text { Index }\end{array}$ & $\Delta$ \\
\hline 1 & 1 & 1 & Journal of Marketing & 441 & 0.499 & 100 & 219.31 \\
\hline 2 & 2 & 2 & Journal of Marketing Research & 388 & 0.280 & 56.02 & 25.65 \\
\hline 3 & 3 & 3 & Journal of Consumer Research & 362 & 0.254 & 50.88 & 107.21 \\
\hline 4 & 4 & 4 & Marketing Science & 279 & 0.147 & 29.39 & 76.84 \\
\hline 6 & 6 & 5 & Journal of Retailing & 156 & 0.070 & 13.99 & 5.20 \\
\hline 5 & 5 & 6 & Journal of The Academy of Marketing Science & 104 & 0.065 & 12.95 & 6.42 \\
\hline 16 & 9 & 7 & Journal of Consumer Psychology & 116 & 0.058 & 11.66 & 3.14 \\
\hline 14 & 7 & 8 & Academy of Management Journal & 70 & 0.055 & 11.03 & 1.68 \\
\hline 7 & 8 & 9 & Journal of International Business Studies & 69 & 0.053 & 10.70 & 3.43 \\
\hline 9 & 10 & 10 & Journal of Business Research & 100 & 0.050 & 10.01 & 0.42 \\
\hline 8 & 13 & 11 & European Journal of Marketing & 89 & 0.050 & 9.92 & 3.32 \\
\hline 11 & 11 & 12 & Management Science & 84 & 0.046 & 9.26 & 1.61 \\
\hline 23 & 12 & 13 & Strategic Management Journal & 68 & 0.045 & 8.94 & 0.95 \\
\hline 12 & 17 & 14 & Annals of Tourism Research & 40 & 0.044 & 8.74 & 3.91 \\
\hline 10 & 15 & 15 & International Journal of Research in Marketing & 87 & 0.040 & 7.96 & 4.16 \\
\hline 13 & 16 & 16 & Journal of Advertising & 66 & 0.036 & 7.13 & 0.22 \\
\hline 15 & 14 & 17 & Academy of Management Review & 58 & 0.035 & 7.08 & 4.01 \\
\hline 18 & 22 & 18 & Tourism Management & 39 & 0.031 & 6.28 & 1.21 \\
\hline 26 & 18 & 19 & Administrative Science Quarterly & 39 & 0.030 & 6.04 & 5.64 \\
\hline 28 & 24 & 20 & Journal of Marketing Management & 44 & 0.024 & 4.91 & 0.38 \\
\hline 33 & 23 & 21 & Journal of Public Policy and Marketing & 46 & 0.024 & 4.83 & 0.83 \\
\hline 25 & 20 & 22 & Industrial Marketing Management & 38 & 0.023 & 4.67 & 4.07 \\
\hline 27 & 19 & 23 & Journal of Service Research & 36 & 0.019 & 3.85 & 0.34 \\
\hline 20 & 25 & 24 & Marketing Letters & 32 & 0.019 & 3.78 & 0.52 \\
\hline 41 & 28 & 25 & Psychology \& Marketing & 36 & 0.018 & 3.68 & 0.81 \\
\hline 29 & 29 & 26 & Journal of Travel Research & 26 & 0.018 & 3.52 & 0.05 \\
\hline 40 & 31 & 27 & Journal of Business Ethics & 24 & 0.017 & 3.51 & 0.04 \\
\hline 87 & 42 & 28 & Journal of Management & 35 & 0.017 & 3.50 & 0.39 \\
\hline 88 & 43 & 29 & Journal of Management Studies & 28 & 0.017 & 3.42 & 0.54 \\
\hline 46 & 32 & 30 & Organization Science & 34 & 0.017 & 3.31 & 0.44 \\
\hline 21 & 21 & 31 & Journal of Advertising Research & 32 & 0.016 & 3.22 & 1.41 \\
\hline 77 & 45 & 32 & American Economic Review & 16 & 0.015 & 2.94 & 0.03 \\
\hline 30 & 26 & 33 & Journal of International Marketing & 27 & 0.015 & 2.94 & 1.13 \\
\hline 60 & 39 & 34 & Journal of Consumer Behaviour & 27 & 0.014 & 2.71 & 0.80 \\
\hline 95 & 35 & 35 & Journal of Business Venturing & 15 & 0.013 & 2.55 & 0.44 \\
\hline 79 & 46 & 36 & Journal of World Business & 21 & 0.012 & 2.46 & 0.51 \\
\hline 62 & 40 & 37 & Journal of Personal Selling and Sales Management & 22 & 0.012 & 2.36 & 0.30 \\
\hline 24 & 27 & 38 & Harvard Business Review & 26 & 0.011 & 2.30 & 0.17 \\
\hline 36 & 30 & 39 & Journal of Product Innovation Management & 18 & 0.011 & 2.26 & 0.16 \\
\hline 128 & 36 & 40 & Journal of Operations Management & 16 & 0.011 & 2.23 & 0.10 \\
\hline 45 & 34 & 41 & Journal of Personality and Social Psychology & 21 & 0.011 & 2.21 & 0.32 \\
\hline 17 & 58 & 42 & International Marketing Review & 20 & 0.011 & 2.14 & 0.19 \\
\hline 67 & 61 & 43 & Marketing Theory & 18 & 0.011 & 2.11 & 0.95 \\
\hline 113 & 44 & 44 & Organization Studies & 14 & 0.010 & 1.92 & 0.04 \\
\hline 90 & 48 & 45 & Journal of Sustainable Tourism & 18 & 0.010 & 1.91 & 0.28 \\
\hline 86 & 65 & 46 & International Business Review & 14 & 0.009 & 1.85 & 0.03 \\
\hline 89 & 49 & 47 & Quantitative Marketing and Economics & 20 & 0.009 & 1.85 & 0.53 \\
\hline 109 & 33 & 48 & Entrepreneurship Theory \& Practice & 11 & 0.009 & 1.74 & 0.53 \\
\hline 150 & 56 & 49 & Organizational Behavior and Human Decision Processes & 19 & 0.008 & 1.63 & 0.31 \\
\hline NR & 152 & 50 & Journal of Hospitality and Tourism Research & 13 & 0.008 & 1.57 & 0.52 \\
\hline
\end{tabular}

Note: $\Delta=$ difference between journal adjacent MAG scores multiplied by 1000. For example, JM - JMR $=.499-.280=.219 \times 1000=219.31$. $\mathrm{NR}=$ not ranked 


\section{Validation}

To further validate the MAG score, correlation analysis of the top 100 MAG score journals was undertaken against the SSCI and Scopus indices (Fam et al. 2011; Steward and Lewis 2010), see Appendix C. In total 97 of the top 100 MAG Scholar journals are included in the SCOPUS index, while 87 are included in the SSCI database. As shown in Table 7, the MAG Scholar ranking is significantly correlated with the Scopus Impact per Publication (IPP), $\mathrm{r}(97)=.215, \mathrm{p}<.05$, and the SSCI Impact Factor $(\mathrm{IF}), \mathrm{r}(87)=.261, \mathrm{p}<.01$. This indicates that the MAG Scholar list is broadly similar to both the Scopus and SSCI indices.

Table 7: Correlation Matrix: MAG, Scopus and SSCI Ranking

\begin{tabular}{l|l|l|l}
\hline & MAG & Scopus & SSCI \\
\hline MAG & 1 & & \\
\hline Scopus IPP & $.215^{*}$ & 1 & \\
\hline SSCI IF & $.261 * *$ & $.810 * *$ & 1 \\
\hline$*$ Correlation is significant at the 0.05 level (2-tailed). \\
* Correlation is significant at the 0.01 level (2-tailed).
\end{tabular}

\section{Conclusion}

In an educational environment that considers performance on the basis of objective measures, publishing in highly ranked journals are an important indicator of perceived quality. The key question is not; are the rankings valid or without bias? but "are there other valid measures of journals rankings?" and "do the rankings indicate quality?" (Lee 2011). This study used the vox populi approach, in addition to self-report publications, in order to introduce an element of crowd sourcing from which to enhance and augment the spectrum of academically ranked journals in the marketing domain.

\section{Journal Ranking}

The top ranked six journals, regardless of region, continue to include: Journal of Marketing, Journal of Marketing Research, Journal of Consumer Research, Marketing Science, Journal of Academy of Marketing Science, and the Journal of Retailing. The contribution from this study is the use of a wide spectrum of academics across multiple countries to gather the ranking data; thus the ranking provides an international perspective by design. In addition, the high correlation results with Scopus and SSCI provides evidence that the MAG rankings are reliable when compared against other ranking indices.

The results also demonstrate that the six top ranked journals remain the most highly ranked even when the US data is removed. This implies a uniform and consistent perception internationally, although this measure of quality may not be well-founded (Herndon 2016). More interestingly is the divergence of journal rankings below the top six. The data set without US data indicates an emphasis on international marketing journals, while the data set including US data rank general management journals higher.

Although there are strong correlations between the MAG method, Scopus, and SSCI, there are large differences in underlying philosophy and in statistical variance. Both 
Scopus and SSCI are actuarial counting of citation rates, and are based on the logical inference that the more a journal's articles are cited, the more prestigious the journal. In contrast, the vox populi method used here captures a broader range of the uses to which published articles are used - such as teaching, consultancy, and contributions to public issues. A case could be made that a focus on research citations too narrowly represents the usefulness of academic research. A sole focus on high citation rates risks becoming a self-fulfilling prophecy, and opens a doorway to academic fraud, where publication in top journals is pursued as an outcome in itself rather than as a marker for practical usefulness or genuine contribution to knowledge. As universities are often subject to publish or perish cultures, and are also sometimes accused of failing to do research that is relevant, a broader means of valuing journals may lead to improved organizational research support, less publish or perish behavior and improved academic well-being (Richard, Plimmer, Fam and Campbell 2015).

There appears to be an increased move toward using and reporting SSCI Impact Factor (IF) to rank the value of the journals. Unfortunately relatively few marketing journals are listed in SSCI, and even fewer have an IF rating greater than 1. Table 8 shows the IF factors for the top twenty business journals published in, as reported by marketing academics.

Table 8: SSCI Impact Factor of Journals that Marketers Publish In

\begin{tabular}{|l|c|c|c|}
\hline Journal & SSCI & Pubs & $\%$ \\
\hline Journal of Marketing & 3.885 & 26 & $1.20 \%$ \\
\hline Journal of Academy of Marketing Science & 3.744 & 27 & $1.25 \%$ \\
\hline Journal of Consumer Research & 3.187 & 19 & $0.88 \%$ \\
\hline Tourism Management & 3.140 & 15 & $0.69 \%$ \\
\hline Journal of Marketing Research & 3.109 & 19 & $0.88 \%$ \\
\hline Journal of Business Research & 2.129 & 69 & $3.19 \%$ \\
\hline Journal of Retailing & 2.014 & 17 & $0.78 \%$ \\
\hline Journal of Consumer Psychology & 2.009 & 20 & $0.92 \%$ \\
\hline Industrial Marketing Management & 1.930 & 31 & $1.43 \%$ \\
\hline Journal of Business Ethics & 1.837 & 17 & $0.78 \%$ \\
\hline International Journal of Research in Marketing & 1.833 & 13 & $0.60 \%$ \\
\hline Marketing Science & 1.647 & 14 & $0.65 \%$ \\
\hline Marketing Letters & 1.508 & 19 & $0.88 \%$ \\
\hline Psychology \& Marketing & 1.367 & 20 & $0.92 \%$ \\
\hline European Journal of Marketing & 1.088 & 37 & $1.71 \%$ \\
\hline Journal of Consumer Behavior & 1.022 & 19 & $0.88 \%$ \\
\hline Journal of Services Marketing & 1.021 & 14 & $0.65 \%$ \\
\hline Journal of Business and Industrial Marketing & 0.973 & 16 & $0.74 \%$ \\
\hline Journal of Advertising Research & 0.825 & 13 & $0.60 \%$ \\
\hline Journal of Marketing Management & NR & 33 & $1.52 \%$ \\
\hline Journal of Consumer Marketing & NR & 18 & $0.83 \%$ \\
\hline Journal of Marketing Theory and Practice & NR & 15 & $0.69 \%$ \\
\hline Australasian Marketing Journal & NR & 13 & $0.60 \%$ \\
\hline SSCI IF = SSCI Impact factor, Pubs = reported marketing publications, & \\
\hline NR = not ranked, \% reports the percentage of the 2,166 publications & & \\
\hline published in SSCI listed journals. & & & \\
\hline
\end{tabular}

As indicated in Table 5, seven factors are considered important to the ranking of academic research journals, but vary widely in the extent to which they are valued by 
academics. The current study shows that citation counts are critical, but account for slightly less than $25 \%$ of a journal's perceived ranking value.

\section{Journal Publications}

The data supplied from respondents with respect to what journals they publish in indicate that UK academics do not publish in top ranked journal publications as often as the USA, Australia, New Zealand and Europe. Referring to Table 3, as a percentage of publications UK academics have a $1.4 \%(3 / 212)$ publication rate in the top six journals; Australia and New Zealand have a $2.4 \%$ publication rate, Asia has a $3.4 \%$ rate and Europe has a 5.7\% publication rate. Given that the top six journals remain relatively stable across regions and over time this should be a concern to UK, Australian and New Zealand researchers and institutions.

\section{Future Research}

Future research should investigate regional differences more fully, including examining the influence of career duration, age and family-life balance. Regional differences are apparent from the journal ranking criteria considered by the respondents. The determination of journal quality, outside of citation and impact continues to come under scrutiny, it is therefore important that additional research explore quality criteria from both a wider academic perspective, and a business impact perspective.

The high drop-out (42.5\%) and non-response rate for a journal ranking survey is a concern, and needs to be investigated more fully. Considering that publishing in highly ranked journals is generally conducive to academic success, one would think that academics would be interested in such a survey and the results (Rynes 2007). Do marketing academics find a survey on journal rankings too mundane? Of little value? Or is assessment and recall of journal ranking too difficult? A number of participants emailed the researchers to indicate they do not agree with journal rankings, and therefore did not participate in the survey.

\section{Limitations}

The sample consisted of 681 self-selected respondents, which may not be representative of all academics. This is a decrease in respondents from 2011. Surveys in which respondents are self-selected will contain an element of bias, especially when the data collected have potential personal and career impact; the results from this survey are no different. However, utilising the vox populi approach and continuing to conduct the survey every three years should build a substantial longitudinal data set.

The importance of emerging journals and attempting to rank them continues to be an issue (Fam et al. 2011). A second concern is finding an acceptable method to capture the dynamic nature of journal rankings, as marketing priorities and activities move forward (Steward and Lewis 2010). 


\section{Acknowledgement}

The authors would like to thank Victoria University of Wellington VBS Small Grant (207911) for financial support.

\section{References}

Fam, K. -S., Shukla, P., Sinha, A., Parackel, M., and Chai, J. C. Y., (2011), "Rankings in the eyes of the beholder: A vox populi approach to academic journal ranking", Asian Journal of Business Research, vol. 1, no. 1, pp. 1-17.

Herndon, N. C., (2016), "Research fraud and the publish or perish world of academia", Journal of Marketing Channels, vol. 23, no. 3, pp. 91-96. doi: 10.1080/1046669X.2016.1186469

Lee, N., (2011), "Reflections on assessing academic quality in marketing, and the UK REF", European Journal of Marketing, vol. 45, no. 4, pp. 477-483. doi: 10.1108/03090561111111299

Richard, J. E., Fam, K. -S., Plimmer, G., and Gerschewski, S., (2012), "An update of the Vox Populi approach to academic journal rankings: 2011 in review", Asia Journal of Business Research, vol. 2, no. 1, pp. 1-18.

Richard, J. E., Plimmer, G., Fam, K. -S., and Campbell, C., (2015), "Publishing success of marketing academics: antecedents and outcomes", European Journal of Marketing, vol. 49, no. 1/2, pp. 123-145. doi: 10.1108/EJM-06-2013-0311

Rynes, S. L., (2007), "Academy of Management Journal editors' forum on rich research", Academy of Management Journal, vol. 50, no. 1, pp. 13-13.

Saunders, J., and Wong, V., (2011), "Manoeuvring towards research decline: The RAE and the decline of Britain's international research standin", European Journal of Marketing, vol. 45, no. 4, pp. 484-512. doi: 10.1108/03090561111111307

Steward, M. D., and Lewis, B. R., (2010), "A comprehensive analysis of marketing journal rankings", Journal of Marketing Education, vol. 32, no. 1, pp. 75-92.

Theoharakis, V., and Hirst, A., (2002)., "Perceptual differences of marketing journals: A worldwide perspective", Marketing Letters, vol. 13, no. 4, pp. 389-402.

Till, B. D., and Baack, D. W., (2005), "Recall and persuasion", Journal of Advertising, vol. 34, no. 3, pp. 47-57. 


\section{Appendix A: List of Countries Included in Each Region}

North America (NA, 247) includes USA (232) and Canada (15).

UK (50).

ANZ (85) includes Australia (58) and New Zealand (27).

Asia (25) includes China (7), Hong Kong (7), India (1), Indonesia (2), Malaysia (4), Republic of Korea (2), Singapore (2), and Thailand (1).

Europe (36) includes Albania (1), Denmark (6), Estonia (1), Finland (4), France (7), Germany (1), Hungary (1), Ireland (6), Netherlands (2), Norway (3), Sweden (2), and Turkey (2).

Rest of the world (ROW, 22) includes Brazil (1), Egypt (1), Israel (2), Jordan (2), Kuwait (2), Lebanon (1), Qatar (1), South Africa (4), Uganda (1), United Arab Emirates (5), United Republic of Tanzania (1), and Uruguay (1).

\section{Appendix B: Example of the MAG score calculation Journal MAG score = $\left.\sum_{j}\left(\left(\mathbf{R}_{i j} / \sum \mathbf{T}_{j}\right)\right) / \mathbf{R a n k}_{j}\right)$}

Note: $=\mathrm{R}_{i j}$ is the number of unaided recalls for the $i^{\text {th }}$ journal $(i=1-632)$ with $j^{\text {th }} \operatorname{rank}(j=1$, $2,3, \ldots, 10)$, and $\mathrm{T}$ is the total number of unaided recalls for all journals with rank $j$. $\mathrm{Rank}_{j}$ represents the rank of the journal.

Example: MAG score for Journal of Marketing

$(276 / 676 / 1)+(58 / 676 / 2)+(43 / 673 / 3)+(35 / 602 / 4)+(11 / 541 / 5)+(10 / 535 / 6)+$ $(3 / 308 / 7)+(4 / 207 / 8)+(0 / 155 / 9)+(1 / 121 / 10)=0.536$

Original source: Fam et al. (2011)

\begin{tabular}{|c|c|c|c|c|c|c|}
\hline $\begin{array}{l}\text { MAG } \\
\text { Rank }\end{array}$ & Journal & $\begin{array}{c}\text { Scopus } \\
\text { IPP }\end{array}$ & $\begin{array}{c}\text { Scopus } \\
\text { Rank }\end{array}$ & $\begin{array}{c}\text { SSCI } \\
\text { IF }\end{array}$ & $\begin{array}{l}\text { SSCI } \\
\text { Rank }\end{array}$ & $\begin{array}{l}\text { MAG } \\
\text { Score }\end{array}$ \\
\hline 1 & Journal of Marketing & 5.20 & 12 & 3.885 & 14 & 0.536 \\
\hline 2 & Journal of Marketing Research & 3.59 & 29 & 3.109 & 30 & 0.330 \\
\hline 3 & Journal of Consumer Research & 3.40 & 32 & 3.187 & 28 & 0.272 \\
\hline 4 & Marketing Science & 2.33 & 59 & 1.647 & 67 & 0.161 \\
\hline 5 & Journal of Academy of Marketing Science & 2.48 & 53 & 3.744 & 19 & 0.109 \\
\hline 6 & Journal of Retailing & 2.85 & 40 & 2.014 & 54 & 0.080 \\
\hline 7 & Academy of Management Journal & 6.99 & 5 & 6.233 & 2 & 0.067 \\
\hline 8 & Journal of International Business Studies & 4.51 & 20 & 3.620 & 20 & 0.059 \\
\hline 9 & Journal of Consumer Psychology & 2.72 & 46 & 2.009 & 55 & 0.057 \\
\hline 10 & Journal of Business Research & 2.64 & 47 & 2.129 & 50 & 0.051 \\
\hline 11 & Management Science & 3.17 & 37 & 2.741 & 37 & 0.050 \\
\hline 12 & European Journal of Marketing & 1.85 & 73 & 1.088 & 79 & 0.045 \\
\hline 13 & Academy of Management Review & 7.22 & 3 & 7.288 & 1 & 0.044 \\
\hline 14 & International Journal of Research in Marketing & 2.46 & 55 & 1.833 & 61 & 0.040 \\
\hline 15 & Strategic Management Journal & 4.45 & 21 & 3.380 & 24 & 0.040 \\
\hline 16 & Journal of Advertising & 2.12 & 66 & 2.288 & 46 & 0.037 \\
\hline 17 & Annals of Tourism Research & 2.93 & 39 & 2.275 & 47 & 0.027 \\
\hline 18 & Journal of Service Research & 3.49 & 31 & 2.462 & 44 & 0.026 \\
\hline 19 & Administrative Science Quarterly & 4.61 & 19 & 5.316 & 7 & 0.025 \\
\hline 20 & Industrial Marketing Management & 2.58 & 50 & 1.930 & 58 & 0.023 \\
\hline 21 & Journal of Advertising Research & 1.10 & 90 & 0.825 & 85 & 0.022 \\
\hline 22 & Tourism Management & 3.99 & 26 & 3.140 & 29 & 0.021 \\
\hline 23 & Journal of Public Policy and Marketing & 1.72 & 77 & 1.150 & 77 & 0.020 \\
\hline 24 & Journal of Marketing Management & 1.62 & 81 & NR & 99 & 0.019 \\
\hline
\end{tabular}


25 Marketing Letters

26 Journal of International Marketing

1.49

83

1.508

69

0.017

27

Harvard Business Review

3.28

3.250

27

0.016

28 Psychology \& Marketing

NR 99

2.249

0.016

29 Journal of Travel Research

1.72

77

$1367-74$

0.016

30 Journal of Product Innovation Management

3.50

$2.905 \quad 32$

0.015

31 Journal of Business Ethics

2.78

30

0.015

32 Organization Science

2.35

58

$2.086 \quad 53$

0.015

33 Entrepreneurship, Theory and Practice

$1.837 \quad 60$

0.014

34 Journal of Personality and Social Psychology

4.22

$3.360 \quad 25$

0.014

35 Journal of Business Venturing

5.29

22

$3.414 \quad 23$

0.013

36 Journal of Operations Management

5.66

10

4.736

9

0.013

37 Journal of Business Logistics

5.49

8

$4.204 \quad 12$

0.012

38 Journal of Applied Psychology

2.56

9

$4.000 \quad 13$

0.012

39 Journal of Consumer Behavior

4.78

51

$\begin{array}{ll}\text { NR } & 99\end{array}$

0.011

40 Journal of Personal Selling and Sales

1.42

Management

41 Journal of Macromarketing

42 Journal of Management

43 Journal of Management Studies

44 Organization Studies

45 Journal of Strategic Management

1.68

85

$3.810 \quad 16$

0.010

46 American Economic Review

47 Journal of World Business

48 Journal of Services Marketing

80

$1.022 \quad 82$

0.010

49 Journal of Sustainable Tourism

6.65

4.95

82

$\begin{array}{ll}\text { NR } & 99\end{array}$

0.010

50 Quantitative Marketing and Economics

3.39

15

1.429

$6.051-3$

0.010

51 Research Policy

52 Management International Review

53 Psychological Science

54 Consumption, Markets \& Culture

NR

$4.260-11$

0.010

NR

33

2.798

0.009

4.12

99

NR 99

0.009

55 MIS Quarterly

56

Organizational Behavior and Human Decision

3.19

3.833

0.009

1.82

36

2.811

15

0.008

2.73

74

1.021

83

0.008

1.02

45

2.480

42

0.008

4.70

92

NR

99

0.008

1.41

18

$\begin{array}{ll}3.470 & 22\end{array}$

0.007

86

$1.076 \quad 80$

0.007

2.23

10

$5.476 \quad 5$

7.05

Processes

57 Journal of Interactive Marketing

58 International Marketing Review

2.85

64

$2.659 \quad 39$

0.006

59 Journal of Finance

60 International Journal of Market Research

5.09

2.25

4

5.384

0.006

61 Marketing Theory

62 British Journal of Management

63 Journal of Supply Chain Management

6.00

0.74

2.21

2.77

40

$2.805 \quad 35$

0.006

64 Environment and Planning

65 International Business Review

66 Journal of Marketing Theory and Practice

67 Transportation Research

68 Journal of Business and Industrial Marketing

69 Decision Sciences

70 Journal of Travel and Tourism Marketing

71 Sloan Management Review

72 Journal of Consumer Affairs

73

International Journal of Physical Distribution \& Logistics Management

74 Organization

4.71

1.77

2.28

1.18

2.48

13

3.256

$\begin{array}{lll}1.588 & 26 & 0.006 \\ 5.105 & 68 & 0.006\end{array}$

63

1.588

5.105

$0.697 \quad 86$

\begin{tabular}{l|l}
8 & 0.006 \\
\hline
\end{tabular}

95

0.006

65

2.673

$38 \quad 0.006$

\begin{tabular}{l|l|l|l}
43 & 2.188 & 49 & 0.005 \\
\hline
\end{tabular}

17

4.571

$10 \quad 0.005$

\begin{tabular}{l|l|l|l|}
76 & 1.460 & 70 & 0.005 \\
\hline & 1.669 & 66 & 0.005 \\
\hline
\end{tabular}

\begin{tabular}{l|l|l|l}
61 & 1.669 & 66 & 0.005 \\
\hline
\end{tabular}

88

\begin{tabular}{l|l|l} 
NR & 99 & 0.004 \\
\hline
\end{tabular}

1.35

1.87

\begin{tabular}{l|l|l|l|}
\hline 53 & 3.769 & 17 & 0.004 \\
87 & 0.973 & 84 & 0.004 \\
\hline 71 & 1.418 & 73 & 0.004
\end{tabular}

\begin{tabular}{l|l|l|l|}
53 & 3.769 & 17 & 0.004 \\
87 & 0.973 & 84 & 0.004 \\
\hline 71 & 1.418 & 73 & 0.004
\end{tabular}

0.004

2.42

71

$\begin{array}{ll}1.418 & 73\end{array}$

0.004

\begin{tabular}{l|l|l|l|l|}
\hline 1.95 & 68 & 2.114 & 51 & 0.004 \\
\hline
\end{tabular}

57

$1.741 \quad 64$

0.004

\begin{tabular}{|l|l|l|l|l|}
1.43 & 84 & 1.053 & 81 & 0.004 \\
\hline
\end{tabular}

\begin{tabular}{|l|l|l|l|l|}
\hline $\mathrm{NR}$ & 99 & 2.101 & 52 & 0.004 \\
\hline 2.33 & 59 & 1.777 & 63 & 0.003 \\
\hline
\end{tabular}




\begin{tabular}{|c|c|c|c|c|c|c|}
\hline 75 & Tourism Analysis & 0.60 & 96 & NR & 99 & 0.003 \\
\hline 76 & Journal of International Management & 2.44 & 56 & 1.982 & 56 & 0.003 \\
\hline 77 & Journal of Small Business Management & 2.50 & 52 & 1.937 & 57 & 0.003 \\
\hline 78 & Human Resource Management Journal & 2.12 & 66 & 1.845 & 59 & 0.003 \\
\hline 79 & Operations Research & 2.27 & 62 & 1.777 & 63 & 0.003 \\
\hline 80 & Information Systems Research & 3.38 & 34 & 3.047 & 31 & 0.003 \\
\hline 81 & Journal of Marketing Education & 0.93 & 93 & NR & 99 & 0.003 \\
\hline 82 & Public Opinion Quarterly & 1.95 & 68 & 1.429 & 72 & 0.003 \\
\hline 83 & California Management Review & 1.86 & 72 & 1.109 & 78 & 0.003 \\
\hline 84 & Journal of Political Economy & 4.01 & 25 & 3.750 & 18 & 0.003 \\
\hline 85 & $\begin{array}{l}\text { International Review of Retail Distribution and } \\
\text { Consumer Research }\end{array}$ & 0.79 & 94 & NR & 99 & 0.003 \\
\hline 86 & Industrial and Corporate Change & 1.92 & 70 & 1.327 & 75 & 0.003 \\
\hline 87 & Journal of Experimental Social Psychology & 2.61 & 49 & 2.500 & 41 & 0.003 \\
\hline 88 & Quarterly Journal of Economics & 8.27 & 2 & 5.538 & 4 & 0.003 \\
\hline 89 & Current Issues in Tourism & 1.09 & 91 & 1.733 & 65 & 0.003 \\
\hline 90 & Business History Review & 0.50 & 97 & 0.634 & 87 & 0.003 \\
\hline 91 & Science & 26.39 & 1 & NR & 99 & 0.002 \\
\hline 92 & International Journal of Advertising & 1.13 & 89 & 1.169 & 76 & 0.002 \\
\hline 93 & Journal of Consumer Culture & 1.80 & 75 & 2.816 & 33 & 0.002 \\
\hline 94 & IEEE Transactions on Engineering Management & 1.72 & 77 & 1.454 & 71 & 0.002 \\
\hline 95 & American Journal of Sociology & 4.03 & 24 & 2.574 & 40 & 0.002 \\
\hline 96 & Small Business Economics & 2.64 & 47 & 1.795 & 62 & 0.002 \\
\hline 97 & Journal of Experimental Psychology & 2.76 & 44 & 2.355 & 45 & 0.002 \\
\hline 98 & Accounting, Organizations and Society & 3.60 & 28 & 2.464 & 43 & 0.002 \\
\hline 99 & Journal of Financial Economics & 5.07 & 14 & 3.541 & 21 & 0.002 \\
\hline 100 & European Journal of Operational Research & 3.11 & 38 & NR & 99 & 0.002 \\
\hline
\end{tabular}

Notes: SSCI: Business, Management; Scopus: Business, Management and Accounting. NR = Not ranked 


\section{Appendix D: MAG scholar journal ranking comparing with and without US data}

\section{Journal with US data}

1 Journal of Marketing

2 Journal of Marketing Research

3 Journal of Consumer Research

4 Marketing Science

5 Journal of Retailing

6 Journal of Consumer Psychology

7 Journal of The Academy of Marketing Science

8 Journal of Business Research

9 European Journal of Marketing

10 International Journal of Research in Marketing

11 Management Science

12 Academy of Management Journal

13 Journal of International Business Studies

14 Strategic Management Journal

15 Journal of Advertising

16 Academy of Management Review

17 Journal of Public Policy and Marketing

18 Journal of Marketing Management

19 Annals of Tourism Research

20 Administrative Science Quarterly

21 Tourism Management

22 Industrial Marketing Management

23 Journal of Service Research

24 Psychology \& Marketing

25 Journal of Management

26 Organization Science

27 Journal of Advertising Research

28 Marketing Letters

29 Journal of Management Studies

30 Journal of Consumer Behaviour

31 Journal of International Marketing

32 Harvard Business Review

33 Journal of Travel Research

34 Journal of Business Ethics

35 Journal of Personal Selling and Sales Management

36 Journal of Personality and Social Psychology

37 Journal of World Business

38 International Marketing Review

39 Quantitative Marketing and Economics
Total Journal without US data

441

388 Journal of Marketing Research

362 Journal of Consumer Research 163

279 Marketing Science

144

156

Journal of the Academy of Marketing Science $\quad 97$

116 Journal of Retailing 56

104 Journal of Consumer Psychology 52

100 Management Science 40

89 Journal of Advertising 28

87 Journal of Business Research 28

84 Academy of Management Journal 24

70 Academy of Management Review 20

69 Strategic Management Journal 20

68 International Journal of Research in Marketing 19

66 Journal of International Business Studies 19

58 Journal of Public Policy and Marketing 19

46 Administrative Science Quarterly 15

44 Quantitative Marketing and Economics 12

Journal of Personal Selling and Sales Management

39 Journal of Service Research 11

39 Marketing Letters 11

38 Harvard Business Review 10

36 Journal of Management 10

36 Decision Sciences 9

35 Journal of Advertising Research 9

34 Journal of International Marketing 9

32 Journal of Operations Management 9

32 Tourism Management 9

28 Annals of Tourism Research 8

27 Journal of Business Logistics 8

27 Journal of Marketing Education 8

26 Journal of Personality and Social Psychology 8

26 Organization Science 8

24 Journal of Consumer Behavior 7

22 Organizational Behavior and Human Decision 7

21 American Economic Review 6

21 European Journal of Marketing 6

20 Industrial Marketing Management 6

20 Journal of Academy of Marketing Science 


\begin{tabular}{|c|c|c|c|}
\hline $\begin{array}{l}40 \text { Organizational Behavior and Human Decision } \\
\text { Processes }\end{array}$ & 19 & Journal of Applied Psychology & 6 \\
\hline 41 Journal of Product Innovation Management & 18 & Journal of Supply Chain Management & 6 \\
\hline 42 Journal of Sustainable Tourism & 18 & Journal of Travel Research & 6 \\
\hline 43 Marketing Theory & 18 & Production and Operations Management & 6 \\
\hline 44 American Economic Review & 16 & Psychology \& Marketing & 6 \\
\hline 45 Journal of Operations Management & 16 & $\begin{array}{l}\text { International Journal of Hospitality } \\
\text { Management }\end{array}$ & 5 \\
\hline 46 Psychological Science & 16 & Journal of Business Ethics & 5 \\
\hline 47 Journal of Business Venturing & 15 & Operations Research & 5 \\
\hline 48 Journal of Macromarketing & 15 & $\begin{array}{l}\text { International Journal of Contemporary } \\
\text { Hospitality Management }\end{array}$ & 4 \\
\hline 49 Management International Review & 15 & Journal of Hospitality and Tourism Research & 4 \\
\hline 50 International Business Review & 14 & Journal of Marketing Theory and Practice & 4 \\
\hline 51 Organization Studies & 14 & $\begin{array}{l}\text { Manufacturing and Service Operations } \\
\text { Management }\end{array}$ & 4 \\
\hline 52 Decision Sciences & 13 & Psychology and Marketing & 4 \\
\hline 53 Journal of Applied Psychology & 13 & Quarterly Journal of Economics & 4 \\
\hline 54 Journal of Hospitality and Tourism Research & 13 & Rand Journal of Economics & 4 \\
\hline 55 Transportation Research & 13 & Cornell Hospitality Quarterly & 3 \\
\hline $\begin{array}{l}56 \text { International Journal of Hospitality } \\
\text { Management }\end{array}$ & 12 & Econometrica & 3 \\
\hline 57 British Journal of Management & 11 & Entrepreneurship, Theory and Practice & 3 \\
\hline 58 Entrepreneurship Theory \& Practice & 11 & European Journal of Operational Research & 3 \\
\hline $\begin{array}{l}59 \text { International Journal of Contemporary } \\
\text { Hospitality Management }\end{array}$ & 11 & International Marketing Review & 3 \\
\hline 60 International Journal of Tourism Research & 11 & Journal of Business and Industrial Marketing & 3 \\
\hline 61 Journal of Marketing Education & 11 & Journal of Consumer Marketing & 3 \\
\hline 62 Journal of Marketing Theory and Practice & 11 & Journal of Ecotourism & 3 \\
\hline 63 Journal of Political Economy & 11 & Journal of Interactive Marketing & 3 \\
\hline 64 Journal of Services Marketing & 11 & Journal of Macromarketing & 3 \\
\hline 65 Journal of Services Research & 11 & Journal of Management Studies & 3 \\
\hline 66 Current Issues in Tourism & 10 & Journal of Product Innovation Management & 3 \\
\hline 67 Human Relations & 10 & Journal of Sustainable Tourism & 3 \\
\hline 68 Journal of Business and Industrial Marketing & 10 & Journal of World Business & 3 \\
\hline 69 Journal of Business Logistics & 10 & Marketing Education Review & 3 \\
\hline 70 Journal of Interactive Marketing & 10 & Psychological Science & 3 \\
\hline 71 Journal of Supply Chain Management & 10 & Sloan Management Review & 3 \\
\hline 72 Quarterly Journal of Economics & 10 & $\begin{array}{l}\text { Academy of Management Learning and } \\
\text { Education }\end{array}$ & 2 \\
\hline 73 Tourism Analysis & 10 & Academy of Management Perspectives & 2 \\
\hline 74 Journal of Experimental Psychology & 9 & Academy of Marketing Science Review & 2 \\
\hline 75 Journal of International Management & 9 & Business History & 2 \\
\hline $\begin{array}{l}76 \begin{array}{l}\text { Manufacturing and Service Operations } \\
\text { Management }\end{array}\end{array}$ & 9 & Business Horizons & 2 \\
\hline 77 Operations Research & 9 & Current Issues in Tourism & 2 \\
\hline
\end{tabular}




\begin{tabular}{|c|c|c|c|}
\hline 78 Production and Operations Management & 9 & Event management An International journal & 2 \\
\hline 79 Consumption, Markets \& Culture & 8 & Global Strategy Journal & 2 \\
\hline 80 Cornell Hospitality Quarterly & 8 & International Journal of Logistics Management & 2 \\
\hline 81 Research Policy & 8 & Journal of Accounting and Economics & 2 \\
\hline 82 Australasian Marketing Journal & 7 & Journal of Accounting Research & 2 \\
\hline 83 Econometrica & 7 & Journal of American Statistical Association & 2 \\
\hline 84 Journal of Finance & 7 & Journal of Business Venturing & 2 \\
\hline 85 Sloan Management Review & 7 & Journal of Consumer Affairs & 2 \\
\hline 86 Advances in Consumer Research & 6 & $\begin{array}{l}\text { Journal of Current Issues and Research in } \\
\text { Advertising }\end{array}$ & 2 \\
\hline 87 Business History & 6 & Journal of Experimental Psychology & 2 \\
\hline 88 Environment and Planning & 6 & Journal of Finance & 2 \\
\hline 89 Journal of Strategic Marketing & 6 & Journal of Financial Economics & 2 \\
\hline 90 Business Ethics Quarterly & 5 & Journal of International Management & 2 \\
\hline 91 European Journal of Information Systems & 5 & Journal of Marketing Management & 2 \\
\hline 92 European Journal of Operational Research & 5 & $\begin{array}{l}\text { Journal of Personal Selling \& Sales } \\
\text { Management }\end{array}$ & 2 \\
\hline 93 Journal of Brand Management & 5 & Journal of Political Economy & 2 \\
\hline 94 Journal of Consumer Marketing & 5 & Journal of Public Policy \& Marketing & 2 \\
\hline 95 Journal of Ecotourism & 5 & Journal of Services Marketing & 2 \\
\hline 96 Journal of Organizational Behavior & 5 & Review of Economics and Statistics & 2 \\
\hline 97 Journal of Retailing and Consumer Services & 5 & Strategic Entrepreneurship Journal & 2 \\
\hline 98 Journal of Travel and Tourism Marketing & 5 & The Accounting Review & 2 \\
\hline 99 Management Information Systems Quarterly & 5 & Tourism Analysis & 2 \\
\hline 100 Service Industries Journal & 5 & Transportation Research & 2 \\
\hline
\end{tabular}

Note: The highlighted listings indicate journals either ranked outside the top 50, or not ranked within the 100 journal listed, (e.g., Journal of Personality and Social Psychology is ranked \#31 with US data included, but is not ranked in the top 100 when US data is not included). 